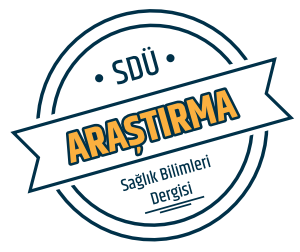

Sdü Sağlık Bilimleri Enstitüsü Dergisi / Cilt 9 Sayı 1 / 2018

\title{
Shear Bond Strength of Veneer Composite to Cobalt-Chromium
} Alloys Fabricated Differently

\section{Veneer Kompozitlerin Farklı Tekniklerle Üretilen Kobalt-Krom Alaşımlara Makaslama Bağlanma Direnci}

\author{
Ayça Tulga ${ }^{1}$ \\ ${ }^{1}$ Ordu University, Faculty of Dentistry, Department of Prosthodontics, Ordu, Turkey.
}

\begin{abstract}
Objective: The purpose of this study was to assess and compare the shear bond strength of a veneer composite resin bonded to cobalt-chromium $(\mathrm{CoCr})$ dental alloys produced by different techniques.

Material-Method: Ninety cylindrical specimens $(10 \mathrm{~mm}$ in diameter, $8 \mathrm{~mm}$ in height) made of $\mathrm{CoCr}$ dental alloys were prepared by conventional casting technique (C), milling (M), LaserCUSING with and without annealing (CL+, CL), and direct metal laser sintering (DMLS) with and without annealing $(\mathrm{EL}+, \mathrm{EL})$. Veneer composite cylinders $(5 \mathrm{~mm}$ in diameter, $3 \mathrm{~mm}$ in height) were built on metal specimens using a silicone jig. After storage in water for 24 hours, the specimens were assessed for bond strength with a shear force test at a crosshead speed of $0.5 \mathrm{~mm} / \mathrm{min}$. The shear bond strengths (SBSs) were statistically analyzed using the Kolmogorow-Smirnow test and Tukey-HSD multiple comparison test $(\alpha=.05)$.
\end{abstract}

Results: When the SBS values of the groups were compared, significant differences were found among the groups $(\mathrm{P}<.05)$. While statistically significant differences were found between the $\mathrm{CL}+$ group (9.36 \pm 2.62$)$ and the $\mathrm{M}$ group (13.34 \pm 2.53$)$ $(\mathrm{P}<.05)$, there were no significant differences among the others $(\mathrm{P}>.05)$. The debonded surfaces of the specimens exhibited mostly mixed type of failures.

Conclusions: The $\mathrm{CoCr}$ alloy fabrication technique has an effect on the SBSs between the veneer composite resin and the metal used. LaserCUSING casting, a new technology, seems to have the lowest metal-resin bond strength among all the techniques tested.

Keywords: Cobalt-chromium alloys, direct metal laser sintering, milling, shear bond strength.

\section{Introduction}

Cobalt-chromium ( $\mathrm{CoCr}$ ) dental alloys have been widely used in prosthodontics because of their superior mechanical properties and lower cost (1). Manufacturing $\mathrm{CoCr}$ dental alloy substructures has been getting progressively easier with the aid of digitalized technologies called computer-aided design/computer-aided manufacturing (CAD/CAM) systems. $\mathrm{CAD} / \mathrm{CAM}$ technology can be differentiated into subtractive manufacturing, such as milling, and additive manufacturing,

\section{Özet}

Amaç: $\mathrm{Bu}$ çalışmanın amacı farklı tekniklerle üretilen kobalt-krom $(\mathrm{Co}-\mathrm{Cr})$ dental alaşımların veneer kompozit rezinlere olan makaslama bağlanma direncinin (MBD) değerlendirilmesi ve karşılaştırılmasıdır.

Materyal-Metot: $\mathrm{Co}-\mathrm{Cr}$ dental alaşımlardan konvansiyonel döküm tekniği (C), frezeleme tekniği (M), LaserCUSING yöntemi tavlama işlemi yapılmıș ve yapılmamış olmak üzere $(\mathrm{CL}+, \mathrm{CL})$ ve direk metal lazer sinterleme (DMLS) yöntemi ile tavlama işlemi yapılmış ve yapılmamış (EL+, EL) olmak üzere toplam 90 adet silindir şeklinde $(10 \mathrm{~mm}$ çapında, 8 $\mathrm{mm}$ yüksekliğinde) örnekler elde edilmiștir. Elde edilen metal örneklerin üzerine silindir șeklinde $(5 \mathrm{~mm}$ çapında, $3 \mathrm{~mm}$ yüksekliğinde) veneer kompozit örnekler silikon bir kalıp aracılığıyla oluşturulmuştur. Hazırlanan örnekler suda 24 saat bekletildikten sonra, bağlantı dayanıklılıkları çapraz kafa hızı $0.5 \mathrm{~mm} /$ dak olmak üzere makaslama testi ile değerlendirilmiştir. Elde edilen MBD değerleri istatistiksel olarak Kolmogorov-Smirnov ve Tukey-HSD çoklu karşılaştırma testi ile analiz edilmiştir $(\alpha=.05)$.

Bulgular: MBD değerleri karşılaştırıldığında, gruplar arasında önemli farklılıklar olduğu bulunmuștur $(\mathrm{P}<.05)$. CL+ $(9.36 \pm 2.62)$ ve $M(13.34 \pm 2.53)$ grubu arasinda istatistiksel olarak önemli fark bulunurken $(\mathrm{P}<.05)$, diğer gruplar arasındaki fark önemsiz bulunmuştur $(\mathrm{P}>.05)$. Örneklere ait bağlantı yüzeyleri genellikle karışık tip başarısızlık göstermiştir.

Sonuç: $\mathrm{Co}-\mathrm{Cr}$ alaşımlarının üretim tekniğinin, çalışmada kullanılan veneer kompozit rezin ve metal arasındaki MBD değerlerini etkilediği gözlenmiştir. Yeni bir teknoloji olan LaserCUSING üretim tekniğinin, test edilen tüm teknikler arasında en düşük metal-rezin bağlantısına sahip olduğu gözlenmektedir.

Anahtar kelimeler: Kobalt-krom alaşımlar, direk metal lazer sinterleme, frezeleme, makaslama bağlanma direnci. such as the recently developed laser sintering (2).

The use of additive manufacturing began after the development of rapid prototyping (RP) in 1980 (3). Common $\mathrm{RP}$ technologies used in dentistry are selective laser sintering (SLS), selective laser melting (SLM), 3D printing (3DP), stereolithography (SLA), and fused deposition modelling (FDM) (2-4). SLS systems involve the incomplete sintering of powder particles in particular regions based on the extent of energy per unit area that the irradiating laser provides (3).

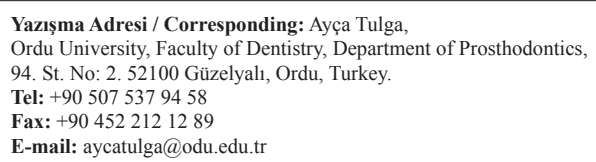


Table 1 . Manufacturer, composition and fabrication process of materials used in this study

\begin{tabular}{|c|c|c|c|}
\hline Material & Manufacturer & Composition (wt\%) & Process \\
\hline Cromoron Premium C & Hersteller, Dg Dental\&Cosmetic, NY & $\begin{array}{c}\text { Co: } 63, \mathrm{Cr}: 24, \mathrm{Mo}: 3 \text {, } \\
\text { W: } 8, \mathrm{Si}: 1, \mathrm{Nb}: 1\end{array}$ & Lost-waxcasting \\
\hline CopraBond $\mathrm{K}$ & $\begin{array}{l}\text { WhitepeaksDental Solutions Gmb- } \\
\text { H\&Co, Germany }\end{array}$ & $\begin{array}{c}\text { Co: } 61, \mathrm{Cr}: 28, \mathrm{~W}: 8.5, \mathrm{Mn}: \\
0.25, \mathrm{Fe}:<0.5, \mathrm{Si}: 1.65, \mathrm{C}:<0.1\end{array}$ & CAD/CAM Milling \\
\hline $\begin{array}{l}\text { EOS CobaltChrome } \\
\text { SP2 powder }\end{array}$ & EOS GmbH, Munich, Germany & $\begin{array}{c}\text { Co: } 61.8 \text { - } 65.8, \text { Cr: } 23.7-25.7, \\
\text { Mo: } 4.6-5.6 \\
\text { W: } 4.9-5.9\end{array}$ & $\begin{array}{c}\text { Direct metal lasersintering } \\
\text { (DMLS) }\end{array}$ \\
\hline $\begin{array}{l}\text { Remanium } \\
\text { star CL }\end{array}$ & $\begin{array}{c}\text { Dentaurum, ConceptLaserGmbH, } \\
\text { Pforzhei, Germany }\end{array}$ & $\begin{array}{c}\text { Co: } 60.5, \text { Cr: } 28, \mathrm{~W}: 9, \text { Si: } 1.5, \\
\text { Other elements: }<1\end{array}$ & LaserCUSING ${ }^{\circledR}$ \\
\hline
\end{tabular}

Through SLM, it is possible to fully melt the metal powder without a great deal of retained porosity, creating objects with almost complete density and intricate structures (7). Nowadays, direct metal laser sintering (DMLS) and SLM are generally used for the fabrication of metal substructures in prosthodontics. DMLS is an SLS system that uses laser sintering of a metal powder in which the metal parts are obtained directly in the building process (4). The fundamental principle of LaserCUSING technology involves the combination of single-component metallic powder materials by means of a laser. This technique is similar to SLM and permits the layer-by-layer formation of components using nearly all metallic substances. Here, metallic powder is completely integrated layer-by-layer to generate a component density of $100 \%$ (5).

When metal substructures are manufactured with sintering techniques, a heat treatment process called "annealing" is performed to shift the material into a state of equilibrium (68 ). This process consists of heating an object over a critical temperature, keeping it at a constant temperature, and then bringing the temperature down (8). Basically, annealing improves an object's ductility, provides rapid relief of internal stress, makes the material softer, and makes the structure homogenous (6-8).

Composite resin veneered metal substructures have been used extensively in such restorations as crowns and too long fixed dental prostheses as well as in removable prostheses and implant supported hybrid prostheses $(9,10)$. Ease of fabrication and repairs, similarity of wear resistance to natural teeth, and cost effectiveness make metal-resin restorations more advantageous than metal-ceramic restorations. In addition, a new generation of veneer composites and adhesive systems make them extremely popular in prosthetic dentistry (11).

The clinical application of metal-resin restorations necessitates a strong and a durable resin to metal bond. Metalresin bonding durability is an important criterion for choosing the type of veneer composite, bonding system, and technique used in these restorations (12). Many studies have evaluated the effects of various composite veneering materials, different surface treatments, and different adhesive primers on metalresin bonding durability (13-17). However, there is little or no information about the effects of different manufacturing techniques on metal substructures to metal-resin bonding. Muratomi et al. evaluated and compared the bond strengths between veneer composite and $\mathrm{CoCr}$ alloys with and without retentive devices manufactured by casting and laser sintering. According to their laser-sintered $\mathrm{CoCr}$ alloy with retentive devices supplied better retention durability for compositeveneered restorations (18).

The present study seeks to assess how the annealing process affects the shear bond strength (SBS) amongst veneer composite resin and $\mathrm{CoCr}$ alloys produced by $\mathrm{RP}$ technologies and to assess the bond abilities of $\mathrm{CoCr}$ dental alloys fabricated with different techniques. The following null hypotheses were developed: 1) the fabrication method would have no effect on the metal-resin bond ability; 2) the annealing process would have no effect on the metal-resin bond ability.

\section{Material-Methods}

\section{Fabrication of metal specimens}

Table 1 lists the CoCr dental alloys used in this study. A total of 90 metal cylindrical specimens $(10 \mathrm{~mm}$ in diameter, $8 \mathrm{~mm}$ in height) ( $\mathrm{n}=15$ per group) were prepared for six experimental groups as follows:

Casting group (group C): For this group, 15 specimens were fabricated using the lost-wax casting technique. Standardization was obtained by utilizing a teflon mold for developing the cast objects with a low shrinkage modelling resin (GC Patern resin; GC America Inc., IL, USA). After the preparation of these resin samples, they were invested with a phosphate-bonded investment (Wirovest; Bego, Bremen, Germany). To fabricate the specimens, a casting machine that had induction heating (INF 2010; Mikrotek Dental, Ankara, Turkey) was used according to the manufacturer's instructions.

Milling group (group M): The milling method was used to fabricate 15 specimens for this group. A CAD program (DWOS software package; Dental Wings Gmbh, Chemnitz, Germany) was used to develop the cylindrical milling samples, and milling machine (D15; Yenadent Ltd., Istanbul, Turkey) was used to process the hard-milling CoCr blocks (CopraBond K) according to the manufacturer's instructions.

DMLS groups (groups EL and EL+): DMLS equipment 


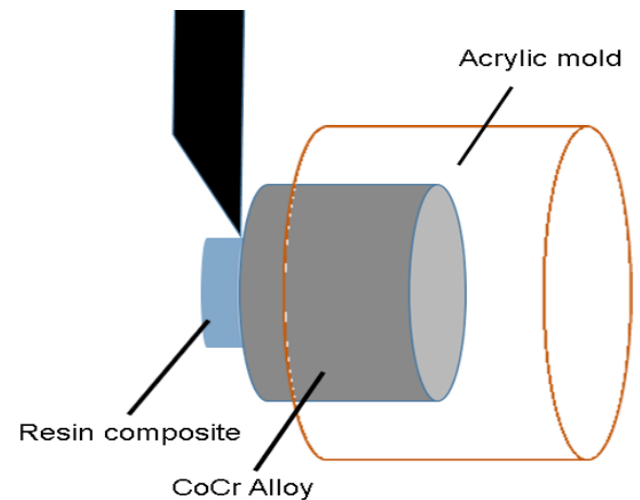

Figure 1. Schematic illustration of bonded specimen for shear test

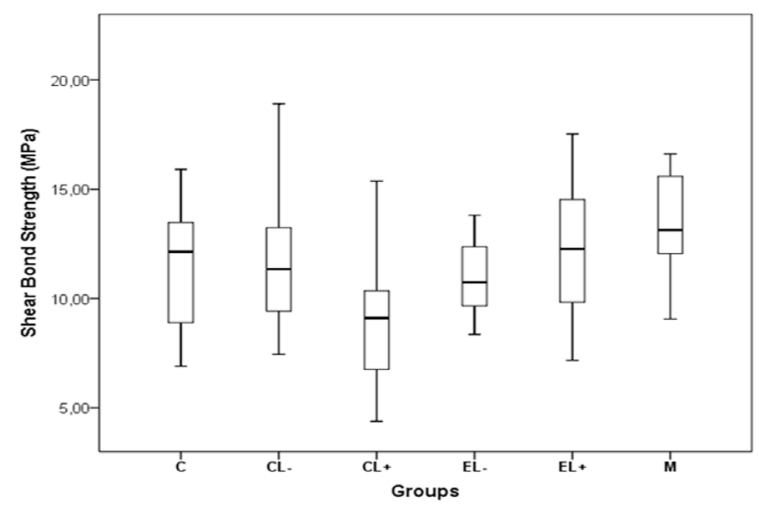

Figure 2. Box plot with the mean bond strengths for metal-ceramic shear bond strengths according to the manufacturing methods (Casting (C), LaserCUSING with (CL+) and without annealing (CL), DMLS with (EL+) and without annealing (EL), Milling (M))

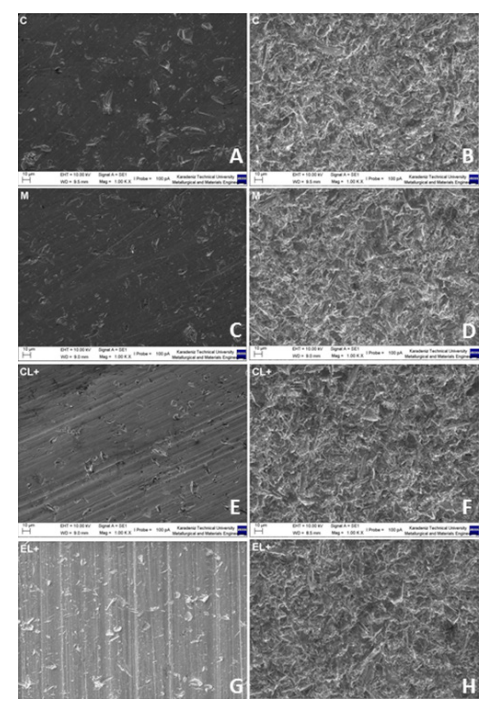

Figure 3. Representative scanning electron micrographs of metal specimens' surfaces belonging to the casting (A, B), milling $(C$, D), LaserCUSING with annealing (E, F) and DMLS with annealing groups $(\mathrm{G}, \mathrm{H})$ before and after sandblasting respectively (original magnification $\times 1000$ )
(EOS M 100; EOS GmbH, Munich, Germany) was used to fabricate 30 samples for groups EL and EL+. Cylindrical sample designs were prepared using CAD (DWOS software package; Dental Wings Gmbh), and were changed into STereoLithography (STL) files, which were then transferred to the EOS M100. The standard specifications for the DMLS technique are suggested by the manufacturer: a scan speed of $7 \mathrm{~m} / \mathrm{s}$, lamination thickness of $30 \mu \mathrm{m}$, focus diameter of 40 $\mu \mathrm{m}$, and $\mathrm{Yb}$-fiber laser power of $200 \mathrm{~W}$. The metal powder had a particle size of $20 \mu \mathrm{m}$.

The annealing process was carried out on $50 \%$ of the specimens to relieve stress; this formed the EL+ group. The recommendations of the metal powder manufacturer (EOS CobaltChrome SP2) were followed for the annealing procedure. The furnace (XD 1600A; Zhengzhou Brother Furnace Co., Ltd., Henan, China) was heated under an argon atmosphere to a temperature of $450^{\circ} \mathrm{C}$ over 60 minutes. This temperature was maintained for 45 minutes. The furnace temperature was then increased to $750^{\circ} \mathrm{C}$ over 45 minutes, and this temperature was kept constant for 60 minutes. After these procedures, no more heat was applied. Once the temperature had fallen to around $300^{\circ} \mathrm{C}$, the annealing process was carried out.

LaserCUSING groups (groups $\mathbf{C L}$ and $\mathbf{C L}+$ ): Thirty specimens were fabricated with the LaserCUSING system (Concept Mlab; Concept Laser GmbH, Lichtenfels, Germany). The same 3D model of the files of cylindrical specimens used for the DMLS groups were transmitted to the Concept MLab cusing. The manufacturer's guidelines were used to perform LaserCUSING: a scan speed of $7 \mathrm{~m} / \mathrm{s}$, focus diameter of $40 \mu \mathrm{m}$, lamination thickness of $25 \mu \mathrm{m}$, and Yb-fiber laser power of $100 \mathrm{~W}$. Half of the specimens were subjected to the annealing process to relieve stress (group CL+). The heat treatment for annealing was performed under an argon atmosphere according to the instructions of the manufacturer of the metal powder (Remanium ${ }^{\circledR}$ star CL). The specimens were heated at a rate of $400^{\circ} \mathrm{C} /$ hour to $1150^{\circ} \mathrm{C}$ and held at this temperature for 1 hour. Then the components were allowed to cool to $300^{\circ} \mathrm{C}$ in the furnace (XD 1600A; Zhengzhou Brother Furnace Co., Ltd.).

\section{Preparation of metal specimens for bonding to the composites}

Prior to the bonding application of the resin material, all metal specimens were sandblasted with $110 \mu \mathrm{m} \mathrm{Al2O} 3$ particles (Basic Classic; Renfert GmbH, Hilzingen, Germany) with a pressure of $0.4 \mathrm{MPa}$ applied for 15 seconds at a distance of 10-15 mm. The specimens underwent ultrasonic cleaning in isopropyl alcohol for 5 minutes, followed by steam cleaning. After the specimens were dried using an oil-free air stream, metal primer (Metal Photo Primer, Shofu Inc., Kyoto, Japan) was applied and allowed to react for 2 minutes.

\section{Veneering the metal specimens}

A piece of masking tape with a circular hole (5 mm diameter) was positioned at the center of each $\mathrm{CoCr}$ alloy specimen to demarcate the bonding area. The first opaque layer (Universal Opaque, Shofu Inc., Kyoto, Japan) was applied and light- 
cured for 1 minute using a laboratory light curing unit (Photopol Light, Dentalfarm, Torino, Italy), then the second layer was applied and light-cured for 3 minutes.

A teflon mold cylinder with an internal diameter of $5 \mathrm{~mm}$ that demarcated the opaque surface of the alloy was used for applying the veneering resin (Solidex, Shofu Inc., Kyoto, Japan) layer by layer. The resin composite veneer was applied in cylindrical forms ( $5 \mathrm{~mm}$ in diameter and $3 \mathrm{~mm}$ in height) onto the metal specimens using a layering technique, and each layer was light-cured for 3 minutes using a laboratory light curing unit.

\section{Shear force test}

The specimens were separately included in mounting resin molds (internal diameter of $25 \mathrm{~mm}$ and height of $20 \mathrm{~mm}$ ) using a custom-made female arrangement. A universal testing instrument (AGS X; Shimadzu Corp., Kyoto, Japan) was used to conduct the SBS test. Figure 1 is a schematic illustration of the bonded specimen for the SBS test. The specimens were set onto the testing device by means of a custom-made holder and loaded at $0.5 \mathrm{~mm} / \mathrm{min}$ with a standard notched cross-head. The SBS values were calculated in megapascals.

\section{Statistical and Failure Mode Analysis}

Six specimens were randomly chosen from each group and their metal surfaces were examined under a fieldemission scanning electron microscope (SEM) (Evo L10; Zeiss, Germany) before and after sandblasting; SEM photomicrographs were taken at x500 and x1000 magnifications for visual inspection.

After the SBS test, the specimen surfaces were examined under a stereomicroscope (Leica MZ12.5; Meyer Ins., Houston, Tex., USA) at x20 magnification to classify the failure modes into three types: adhesive, cohesive, and mixed failure.

The SBS values were statistically analyzed using a statistical software package (SPSS V22.0; SPSS Inc., Chicago, USA). Variance analysis (Kolmogorov-Smirnov) and the TukeyHSD multiple comparison test were used for analysis and $\alpha=.05$ was selected as the error rate.

\section{Results}

The statistical results of SBS testing were summarized in Table 2 and Figure 2. Comparison indicated significant variations among the SBS values of the various groups $(\mathrm{P}<.05)$. The SBS test results showed that the different methods used to fabricate the $\mathrm{CoCr}$ dental alloys had significant effects on their bond strengths $(\mathrm{P}<.05)$.

When the SBS values of groups were compared to each other, significant differences were noted between the $M$ $(13.34 \pm 2.53)$ and $C L+(9.36 \pm 2.62)(\mathrm{P}<.05)$ groups. However, there were no significant differences among the other groups $(\mathrm{P}>.05)$. The SBS test results also showed that the annealing process had a considerable effect on the bond strength of the LaserCUSING groups $(\mathrm{P}<.05)$.

The SEM images of the surfaces of the metal specimens belonging to the $\mathrm{C}, \mathrm{M}, \mathrm{EL}+$, and $\mathrm{CL}+$ groups before and after sandblasting were represented in Figure 3.

Regarding the failure types, most of the groups presented a predominance of mixed failures: adhesive failure between the metal and resin and cohesive failure in the veneering resin. Only the EL group showed a predominance of the adhesive failure type $(60 \%)$. The cohesive failure was seen only in the $\mathrm{C}, \mathrm{M}$, and $\mathrm{CL}+$ groups and each group showed 1 or 2 cohesive failures.

Tablo 2. Statistical result of the metal-resin SBS test

\begin{tabular}{cccc} 
Groups & $\begin{array}{c}\mathbf{X}(\text { Mean }) \pm \mathbf{S} \\
\text { (Standart error) }\end{array}$ & F ratio & p-value \\
$\mathrm{C}$ & $11.93 \pm 3.86^{\mathrm{AB}}$ & & \\
$\mathrm{M}$ & $13.34 \pm 2.53^{\mathrm{A}}$ & & \\
$\mathrm{EL}+$ & $12.42 \pm 3.03^{\mathrm{AB}}$ & & \\
$\mathrm{EL}$ & $10.76 \pm 2.31^{\mathrm{AB}}$ & 3.38 & .008 \\
$\mathrm{CL}+$ & $9.36 \pm 2.62^{\mathrm{B}}$ & & \\
$\mathrm{CL}$ & $12.06 \pm 2.97^{\mathrm{AB}}$ & & \\
\hline
\end{tabular}

Mean values represented with the same superscript uppercase letters are not significantly different according to Tukey-HSD multiple comparison test $(\mathrm{P}<.05)$.

\section{Discussion}

In the results of the present study, the milling technique showed higher SBS values between the $\mathrm{CoCr}$ alloy and the resin composite veneer than for the other fabrication techniques. However, the results showed statistically significant differences only between the LaserCUSING with annealing process and the milling techniques. Therefore, we rejected the null hypotheses that the fabrication technique and the annealing procedure for the $\mathrm{CoCr}$ alloys would have no effect on the metal-resin bond strength.

Sunitha et al. evaluated and compared the bond strengths of three composite resin veneering materials (SR Adoro, Targis, Tescera) to metal, cured by different methods. According to their study, curing methods using light, heat, and pressure showed the highest bond strengths in all techniques (19). On the other hand, Petridis et al. revealed that Artglass, a composite veneer that uses a light curing method, showed statistically similar bond strengths to metal-ceramic bonding (20). In the present study, a composite veneer fabricated with a light curing method (Solidex, Shofu) was used to minimize the effects of laboratory procedures on metal-resin bonding strength. Actually, many studies have shown that metalresin bonding is generally affected by surface treatments of the bonding area and adhesive systems (13-17). To enhance metal-resin bonding, retention beads are frequently used and are suggested in metal-resin restorations, but macromechanical retention devices have many disadvantages, such as causing an overcontoured resin veneered restoration or an unpleasing esthetic result caused by reverberating of the retention beads under the composite veneer $(13,16,18)$. In this study, no macro-mechanical retention devices were used because the aim of this study was to assess and compare 
the effects of different fabrication techniques for $\mathrm{CoCr}$ alloy on metal-resin bonding. Muratomi et al. showed that metal substructures with retention devices fabricated by laser sintering (DMLS) had higher SBS values than those fabricated by casting, while there were no statistical differences between the two techniques when the metal specimens were prepared without retention devices (18). Similar to the results of the present study, there were no significant differences between the casting and the DMLS groups.

Generally, SBS tests are used for evaluating bonding strengths in in-vitro studies, as the shear forces simulate the occlusal contact forces in the masticatory system (13-17); (20-22). As previous studies have revealed, the surface characteristics of the bonding area affects the SBS values (14-17). In this study, when comparing the SEM images that were taken before sandblasting, a distinct difference could be seen between the surface characteristics of the milling group and the laser sintering groups (Figs. 3C, 3E, and 3G). While the specimen from the milling group was smooth, regular, and had a few cracks on the surface of the bonding area (Fig. 3C), LaserCUSING and DMLS specimens had scratched surfaces with cracks (Figs. 3E and 3G) because of the additive layering fabrication technique. However, the SEM images taken after sandblasting showed no distinct differences among all the groups (Figs. 3B, 3D, 3F, and 3H). Although the sandblasted specimens from all groups had similar SEM images, there were statistically significant variations in SBS values between the milling and LaserCUSING with the annealing process groups. These results could be related to the effect of the fabrication technique on the mechanical properties of CoCr dental alloys $(23,24)$. Al Jabbari et al. revealed that the microstructure and hardness of $\mathrm{CoCr}$ dental alloys are dependent on the fabrication technique employed and showed that higher hardness was observed in $\mathrm{CoCr}$ alloys fabricated by laser sintering than with alloys fabricated by casting and milling techniques (24). Therefore, in the present study, the milling groups' metal specimens must have been more affected by the surface treatment of sandblasting with $110 \mu \mathrm{m} \mathrm{Al} 2 \mathrm{O} 3$ particles than the specimens made using LaserCUSING in the annealing group.

LaserCUSING is a new technology based on the combination of single-component metallic powder materials by means of a laser (5). The present study also revealed that metal-resin bonding was affected by the application of an annealing process after manufacturing $\mathrm{CoCr}$ alloys using laser sintering. This is evidenced by the fact that while the LaserCUSING group without annealing showed no statistically significant differences from the other groups, the LaserCUSING group with annealing showed statistically lower bond strength than the milling group. This result could also be related to the effect of the annealing process on the mechanical properties of $\mathrm{CoCr}$ dental alloys. Ayyıldız et al. revealed that hardness values in $\mathrm{CoCr}$ dental alloys increased after the annealing process of the alloys fabricated using the laser sintering technique (6). However, both of the laser sintering groups used in the present study didn't show the similar results when compared to the milling group. In the SEM images, minor variations between the two laser sintering methods also could be seen. According to the SEM images, the metal surface of LaserCUSING method had thinner lamination marks and smoother surface than the metal surface of DMLS. These differences between two laser sintering methods might be attributed to the different specifications such as lamination thickness, Yb-fiber laser power used for fabrication of $\mathrm{CoCr}$ alloys with different laser sintering machines. Additionally, the difference in test results between two laser sintering methods could be attributed to the suffusion capacity of the primer agent on the metal surface. The primer agent could be suffused easily on the surfaces of CoCr alloys fabricated with DMLS contrast to the LaserCUSING method due to the difference in the thickness of the lamination marks.

The limitation of this study is that no ageing procedures, such as thermal cycling, were applied to the specimens. As revealed in previous studies, metal-resin bonding is affected by thermal cycling and the effect was the same for all tested metal-resin systems $(22,25)$. As the purpose of this study was to evaluate the effects of fabrication techniques and the annealing process on metal-resin bonding, the hypothesis would not change if thermocycling had been applied. In addition, clinical studies are needed to evaluate metal-resin restorations and further in vitro studies should be conducted regarding the mechanical and physical properties of metalresin restorations fabricated by the LaserCUSING technique.

\section{Conclusion}

Within the limitations of this in vitro study, the present results showed that the fabrication techniques affected the SBS between the $\mathrm{CoCr}$ alloy and composite veneer resin. The results also showed that the annealing process differently affected the SBS of metal-resin restorations manufactured by the DMLS and LaserCUSING techniques. While the annealing process had no effect on metal-resin bond strengths in restorations fabricated by DMLS, it had a decreasing effect on those fabricated by the LaserCUSING technique. Furthermore, the LaserCUSING technique seemed to be less promising for the fabrication of metal-resin restorations than the other fabrication techniques used.

\section{References}

1. Wataha JC. Alloys for prosthodontic restorations. J Prosthet Dent 2002;87:351-63.

2. Noort RV. The future of dental devices is digital. Dent Mater 2012;28:3-12.

3. Chua CK, Leong KF, Lim CS. Rapid Prototyping. In: Kai C, Fai K, Sing C, editors. Powder-based rapid prototyping systems. 3th ed., Singapore: World Scientific Publishing Co. 2010. p.199-300.

4. Azari A, Sakineh N. The evolution of rapid prototyping in dentistry: a review. Rapid Prototyp J 2009;15:216-25.

5. Sinirlioğlu MC. Rapid manufacturing of dental and medical parts via LaserCUSING technology using titanium and $\mathrm{CoCr}$ powder materials. Workshop on Rapid Technologies; 2009 Sept 24th; Turkey. 
6. Ayyıldız S, Soylu EH, İde S, Kılıç S, Sipahi C, Pişkin B et all. Annealing of Co-Cr dental alloy: effects on nanostructure and Rockwell hardness. J Adv Prosthodont 2013;5:471-8.

7. Guo WH, Brantley WA, Li D, Clark WAT, Monaghan P, Heshmati RH. Annealing study of palladium-silver dental alloys: Vickers hardness measurements and SEM microstructural observations. J Mater Sci Mater Med 2007; 18:111-8.

8. Chen CL, Tatlock GJ, Jones AR. Effect of annealing temperatures on the secondary re-crystallization of extruded PM2000 steel bar. J Microsc 2009;233:474-81.

9. Rosentritt M, Behr M, Brückner H, Handel G. Composite veneering of metal based fixed partial dentures. J Oral Rehabil 2005;32:614-9.

10. Drago Carl, Lynn Gurney. Maintenance of implant hybrid prostheses: clinical and laboratory procedures.J Prosthodont 2013;22: 28-35.

11. Jandt KD, Bernd WS. Future perspectives of resin-based dental materials. Dent Mater 2009;25:1001-6.

12. Kern M, Thompson VP. Durability of resin bonds to a cobalt-chromium alloy. J Dent 1995;23:47-54.

13. Grover N, Nandlal B. An in vitro evaluation of the effect of sandblasting and laser surface treatment on the shear bond strength of a composite resin to the facial surface of primary anterior stainless steel crowns. J Clin Exp Dent 2015;7:11925.

14. Sarafianou A, Seimenis I, Papadopoulos T. Effectiveness of different adhesive primers on the bond strength between an indirect composite resin and a base metal alloy. J Prosthet Dent 2008;99:377-87.

15. Egoshi T, Tarra Y, Soeno K, Sawase T. Effects of sandblasting, $\mathrm{H} 2 \mathrm{SO} 4 / \mathrm{HCl}$ etching, and phosphate primer application on bond strength of veneering resin composite to commercially pure titanium grade 4. Dent Mater J 2013;32:219-27.
16. Patil SS, Kontham UR, Kamath A, Kontham R. Shear bond strength of composite resin bonded to preformed metal crowns for primary molars using a universal adhesive and two different surface treatments: an in vitro study. Eur Arch Paediatr Dent 2016;17:377-80.

17. Janda R, Roulet JF, Latta M, Damerau G. Spark erosion as a metal-resin bonding system. Dent Mater 2007;23:193-7.

18. Muratomi R, Kamada K, Taira Y, Higuchi S, Watanabe I, Sawase T. Comparative study between laser sintering and casting for retention of resin composite veneers to cobaltchromium alloy. Dent Mater J 2013;32:939-45.

19. Sunitha N, Ariga P, Jain AR, Philip JM. An in vitro evaluation of flexural bond strength of indirect composites fused to metal. J Indian Prosthodont Soc 2013;13:122-7.

20. Petridis H, Garefis P, Hirayama H, Kafantaris NM, Koidis PT. Bonding indirect resin composites to metal: part 2. Effect of alloy surface treatment on elemental composition of alloy and bond strength. Int J Prosthodont 2004;17:77-82.

21. Petridis H, Garefis P, Hirayama H, Kafantaris NM, Koidis PT. Bonding indirect resin composites to metal: part 2. Effect of alloy surface treatment on elemental composition of alloy and bond strength. Int J Prosthodont 2004;17:77-82.

22. Petridis H, Hirayama H, Kugel G, Habib C, Garefis P. Shear bond strength of techniques for bonding esthetic veneers to metal. J Prosthet Dent 1999;82:608-14.

23. Gu D, Shen Y. Balling phenomena in direct laser sintering of stainless steel powder: Metallurgical mechanisms and control methods. Mater Des 2009;30:2903-10.

24. Al Jabbari YS, Koutsoukis T, Barmpagadaki X, Zinelis S. Metallurgical and interfacial characterization of PFM Co-Cr dental alloys fabricated via casting, milling or selective laser melting. Dent Mater 2014;30:79-88.

25. Kim JY, Pfeiffer P, Niedermeier W. Effect of laboratory procedures and thermocycling on the shear bond strength of resin-metal bonding systems. J Prosthet Dent 2003; 90: 1849. 